MAKSIMUM: Media Akuntansi Universitas Muhammadiyah Semarang, Vol.10(1) 2020, 31-40

https://jurnal.unimus.ac.id/index.php/MAX

Registered with the Indonesian Institute of Sciences with p-ISSN: 20872836 and e-ISSN: 2580-9482

\title{
Analisis Faktor-Faktor yang Mempengaruhi Kualitas Audit Internal: Studi pada Inspektorat Provinsi Maluku
}

\author{
Piter Arson Welay
}

Fakultas Ekonomi dan Bisnis, Universitas Pattimura

\begin{tabular}{|c|c|}
\hline Info Article & Abstract \\
\hline $\begin{array}{l}\text { History Article: } \\
\text { Submitted: } 5 \text { Februari } \\
2020 \\
\text { Revised: } 18 \text { Februari } \\
2020 \\
\text { Accepted: } 3 \text { Maret } 2020 \\
\text { Keywords: } \\
\text { word 1; word 2; word; } 3 \text {; } \\
\text { word 4; keywords at } \\
\text { least contain three } \\
\text { words. } \\
\text { JEL classifications: } \\
\text { H83, M42 }\end{array}$ & $\begin{array}{l}\text { This study aims to test empirically the effect of competence, independence, work } \\
\text { experience and internal control systems. using } 61 \text { samples of employees who work } \\
\text { as auditors in the inspectorate of Maluku Province, Ambon City and West Seram } \\
\text { Regency, the data analysis method uses SEM-PLS with the help of the WarpPLS } \\
6.0 \text { application. The results show that competence has no effect on audit quality, } \\
\text { this is because the demographics of respondents have competencies that are not } \\
\text { in accordance with the standards, so that in the last few years they have received } \\
\text { a fair with exception audit opinion. Independence has a positive effect on audit } \\
\text { quality, auditors who are always objective in carrying out the audit process will } \\
\text { produce quality audits. Work experience has a positive effect on audit quality, the } \\
\text { more experienced the auditor, the easier it will be to detect audit problems. The } \\
\text { internal control system is able to strengthen the relationship between competence, } \\
\text { independence and job satisfaction on audit quality, this shows that a good internal } \\
\text { control system will support the creation of a quality audit. }\end{array}$ \\
\hline
\end{tabular}

How to Cite: Welay. (2020). Analisis Faktor-Faktor yang Mempengaruhi Kualitas Audit Internal: Studi pada Inspektorat Provinsi Maluku. MAKSIMUM, Vol.1O(1), 31-40

\footnotetext{
${ }^{\square}$ correspondence Address: Jl. Ir. M. Putuhena, Poka, Tlk. Ambon, Kota Ambon, Maluku 2086-0668 (P-ISSN) Institutional address: Universitas Pattimura Ambon E-mail: piterwelay@gmail.com 


\section{PENDAHULUAN}

Reformasi birokrasi yang dilakukan oleh berbagai instansi pemerintah adalah sebagai salah satu komitmen dalam membangun good governance. Instansi pemerintah dituntut untuk menyajikan laporan keuangan yang berkualitas dan akuntabel serta transparan. Laporan keuangan yang berkualitas perlu dilakukan audit internal untuk memastikan apakah laporan keuangan suatu entitas atau organisasi menyajikan hasil operasi yang wajar dan apakah informasi keuangan tersebut disajikan dalam bentuk yang sesuai dengan kriteria atau aturan-aturan yang telah ditetapkan.

Audit intern berfungsi untuk menilai suatu instansi pemerintah telah melaksanakan kegiatan sesuai dengan tugas dan fungsinya secara efektif dan efisien serta sesuai dengan rencana, kebijakan yang telah ditetapkan. Selain itu, audit internal atas penyelenggaraan pemerintah-an diperlukan untuk mendorong terwujud-nya good governance dan clean government serta mendukung penyelenggaraan pemerintahan yang efektif, efisien, transparan, akuntabel serta bersih dan bebas dari praktik korupsi, kolusi dan nepotisme (Parasayu \& Rohman, 2014).

Pelaksanaan audit internal yang dilakukan oleh inspektorat kota atau kabupaten diatur dalam PP Nomor 60 Tahun 2008 Tentang Sistem Pengendalian Internal Pemerintah, sebagai salah satu Aparat Pengawasan Intern Pemerintah (APIP) yang bertanggung jawab langsung kepada walikota atau bupati. Peraturan pemerintah nomor 12 tahun 2017 pasal 10 ayat (1) huruf (b) menyebutkan bahwa tugas pengawasan merupakan tugas inspektorat. Standar Audit internal APIP sebagaimana diatur dalam PERMENPAN nomor PER/05/M.PAN/03/2008, di-pergunakan sebagai acuan bagi seluruh APIP dalam melaksanakan audit. Standar umum dalam standar audit tersebut antara lain mengatur tentang independensi APIP dan objektivitas auditor.

Audit Internal adalah suatu fungsi penilaian yang dikembangkan secara bebas yang dilakukan oleh orang yang profesional yang memiliki pemahaman yang mendalam mengenai sistem dan kegiatan operasional organisasi, menjamin kegiatan operasional organisasi telah berjalan efektif dan efisien serta memastikan bahwa sasaran dan tujuan organisasi telah tercapai. Lemahnya pengendalian internal dalam penye-lenggaraan peme-rintahan daerah merupakan salah satu penyebab terjadinya ketidakefisienan dan ketidakefektifan penyeleng-garaan pemerintahan daerah dan tentunya berdampak pada pemborosan anggaran dan keuangan daerah. Masih menjadi tanda tanya besar di kalangan profesi audit internal mengenai sejauh mana peran serta dari fungsi pengawasan termasuk para pejabat pengawas yang berada di lingkungan fungsi pengawasan atau inspektorat daerah, baik tingkat provinsi, kabupaten, maupun kota.

Peran dan kinerja inspektorat daerah kini tengah menjadi sorotan masyarakat. Inspektorat adalah instansi yang bertugas untuk mengawasi kinerja pemerintah, pada beberapa tahun terakhir tidak efektif, terbukti dengan OTT yang melibatkan kepala daerah dan bahkan inspektorat hanya digunakan untuk melegitimasi kinerja pemerintah (Gamar dan Djamhuri, 2015). Auditor Internal yang seharusnya dapat menjadi alat deteksi dini dari berbagai penyimpangan, tidak menunjukkan kualitas audit internal secara optimal. Hal ini terbukti dari berbagai bentuk temuan yang ternyata ditemukan oleh Badan Pemeriksa Keuangan Republik Indonesia (BPK RI), bukan oleh Auditor Internal Inspektorat Daerah.

Penelitian ini dilakukan di Provinsi Maluku dan beberapa pemerintah kota di Provinsi tersebut. Temuan BPK mengungkapkan terdapat kerugian negara Rp. 1,291.325.170 ini disebabkan karena belanja barang atau pengadaan barang/jasa fiktif, belanja perjalanan dinas fiktif, perjalanan dinas ganda dan/atau melebihi standar yang ditetapkan, belanja tidak sesuai atau diberikan kepada yang tidak berhak menerimanya atau melebihi ketentuan berupa gaji, tunjangan, honor dan perhitungan bantuan parpol di kota Ambon. Selain itu, BPK menemukan 2. Permasalahan aset tetap, termasuk peralatan dan mesin senilai Rp 10,5 miliar yang tidak ditemukan keberadaannya. Penerimaan bantuan keuangan sebesar Rp 4,3 miliar, penerimaan hibah senilai Rp 14,3 miliar dan penerimaan dana BOS yang belum menyampaikan laporan pertanggungjawabannya. Selain itu juga terdapat pengelolaan keuangan fasilitasi Diklat 
pada Badan Diklat sebesar Rp 14,4 miliar yang dilakukan di luar mekanisme APBD. (www.terasmaluku.com, 2019).

Fenomena-fenomena tersebut, menunjukkan belum efektifnya fungsi audit dan masih lemahnya kualitas audit internal Pemerintah Provinsi Maluku, Pemerintah Kota Ambon, Kabupaten Seram Bagian Barat dan selama lima tahun terakhir beberapa kabupaten/kota tersebut mendapatkan opini audit wajar dengan pengecualian. Sehingga, peneliti tertarik untuk membuktikan secara empiris faktor-faktor yang mempengaruhi kualitas audit internal.

Menurut teori atribusi dan teori stewardship, faktor-faktor yang mempengaruhi kualitas audit adalah kompetensi, independensi, pengalaman kerja dan sistem pengendalian internal. Pegawai pelaksana audit internal yang memiliki kompetensi yang tinggi, maka akan menghasilkan audit yang berkualitas. Pegawai yang independen dalam melaksanakan audit dan dalam mengambil keputusan tidak memihak salah satu pengguna informasi dan selalu obyektif dalam membuat opini audit, maka akan menghasilkan audit yang berkualitas. Pengawai yang memiliki pengalaman audit yang banyak akan menghasilkan audit yang berkualitas, karena dengan mudah mendeteksi kesalahan-kesalahan. Sistem pegendalian internal yang baik dalam suatu instansi pemerntah maka akan mngendalikan prilaku-prilaku yang menyebabkan fraud.

Berdasarkan penelitian empiris sebelumnya faktor-faktor yang mempengaruhi kualitas audit internal menunjukkan hasil yang beragam. Ini menunjukkan bahwa kesenjangan penelitian masih terjadi dalam penelitian tentang faktor-faktor yang mempengaruhi kualitas audit internal. Perbedaan yang terjadi pada hasil penelitian sebelumnya bisa karena sampel yang berbeda, pengukuran variabel yang berbeda, dan adanya variabel lain (variabel atau kontrol independen) yang memengaruhi hubungan antara faktor-faktor yang mempengaruhi kualitas audit. Penelitian ini memberikan penambahan variabel moderasi yaitu sistem pengendalian internal, yang diharapkan bisa mendapatkan hasil yang lebih baik.

\section{Pengaruh kompetensi terhadap kualitas audit Internal}

Kompetensi auditor adalah kemampuan auditor untuk mengaplikasikan pengetahuan dan pengalaman yang dimilikinya dalam melakukan audit sehingga auditor dapat melakukan audit dengan teliti, cermat, intuitif, dan obyektif. Oleh karena itu, dapat dipahami bahwa audit harus dilaksanakan oleh orang yang memiliki keahlian dan pelatihan teknis cukup sebagai auditor. Kompetensi sangat menentukan kualitas audit yang dihasilkan, semakin tinggi kompetensi seorang auditor maka semakin baik kualitas audit yang dihasilkan. Penelitian empiris yang dilakukan oleh Efendy (2010), Ramadhanis (2012), dan Syahputra, dkk., (2015) menunjukkan bahwa variabel kompetensi berpengaruh positif terhadap kualitas audit. Hal tersebut berarti kompetensi auditor memiliki pengaruh terhadap kualitas auditor internal dan auditor yang kompeten akan mudah dalam mencapai tujuan audit.

H1 : Kompetensi auditor berpengaruh positif terhadap kualitas audit internal.

\section{Pengaruh Independensi ter-hadap kualitas audit Internal}

Independensi merupakan sikap auditor yang tidak memihak, tidak mempunyai kepentingan pribadi, dan tidak mudah dipengaruhi oleh pihak-pihak yang berkepentingan dalam memberikan pendapat atau simpulan, sehingga dengan demikian pendapat atau simpulan yang diberikan tersebut berdasarkan integritas dan objektivitas yang tinggi. Independensi auditor merupakan salah satu faktor yang penting untuk menghasilkan audit yang berkualitas. Karena jika auditor kehilangan independensinya, maka laporan audit yang dihasilkan tidak sesuai dengan kenyataan yang ada sehingga tidak dapat digunakan sebagai dasar pengambilan keputusan (Supriyono, 1988). Studi empiris mengungkapkan bahwa independensi merupakan faktor yang sangat menentukan kualitas audit (Ramadhani, 2012: Syahputra, 2015: Ramadhanis, 2012: dan Syahputra,et.al, 2015).

H2 :Independensi berpengaruh positif terhadap kualitas audit internal. 


\section{Pengaruh Pengalaman Kerja Terhadap Kualitas Audit Internal}

Pengalaman auditor merupakan suatu proses pembelajaran dan perkembangan potensi tingkah laku auditor selama berinteraksi dengan tugas yang dilakukan selama rentang waktu tertentu. Semakin banyak pengalaman kerja seorang auditor maka kualitas audit yang dihasilkan akan semakin baik. Studi empiris yang dilakukan oleh Syahputra, et.al (2015), menyatakan bahwa pengalaman auditor berpengaruh positif terhadap kualitas audit yang dihasilkan.

H3: Pengalaman kerja berpengaruh positif terhadap kualitas audit internal.

\section{Sistem Pengendalian Internal Sebagai Modeator Hubungan Kompetensi, Independensi Dan Pengalaman Kerja Terhadap Kualitas Audit Internal}

Sistem pengendalian internal pemerintah adalah sistem pengendalian intern yang diselenggarakan secara menyeluruh dilingkungan pemerintah pusat dan pemerintah daerah. Tujuan dari pengendalian intern diterapkan yaitu agar laporan keuangan andal, efisiensi dan efektivitas dan efisiensi terhadap kegiatan operasi pemerintah serta kepatuhan terhadap hukum dan peraturan. Sistem pengendalian internal sebagai sarana pengendalian aktivitas baik keuangan maupun non keuagan untuk memastikan perlindungan atas aset, deteksi dan pencegahan penipuan, memenuhi persyaratan dan prosedur kebijakan internal control dan akurasi kelengkapan catatan (Abiola et al., 2013). H4 : Sistem pengendalian internal memperkuat pengaruh kompetensi terhadap kualitas audit internal.

H5 : Sistem pengendalian internal memperkuat pengaruh independensi terhadap kualitas audit internal.

H6 : Sistem pengendalian internal memperkuat pengaruh pengalaman kerja terhadap kualitas audit internal.

\section{METHOD}

\section{Rancangan penelitian}

Metode yang digunakan dalam penelitian ini adalah metode kuantitatif dengan tipe penlitian kausal komparatif (causal-comparatif research). Penelitian kausal komparatif adalah penelitian yang karakteristik masalahnya berupa hubungan sebab akibat antar variabel (Indriantoro dan Soepomo, 2016:27). Penelitian ini berusahan untuk menganalisis faktor-faktor yang mempengaruhi kinerja kualitas audit yang diprediksi menggunakan variabel kompetensi, independensi, pengalaman kerja dan sistem pengendalian internal. Penelitian ini merupakan penelitian survei dan data dikumpulkan melalui kuesioner.

\section{Populasi dan sampel}

Populasi dalam penelitian ini adalah seluruh auditor yang bekerja di Inspektorat Provinsi Maluku, Inspektorat Kota Ambon dan Inspektorat Kabupaten Seram Bagian Barat. Teknik sampling yang digunakan dalam penelitian ini adalah sampel jenuh. Sampling jenuh adalah teknik penentuan sampel bila semua anggota populasi digunakan sebagai sampel. Hal ini sering dilakukan bila jumlah populasinya relatif kecil, kurang dari 70 orang. Sampel jenuh disebut juga dengan istilah sensus, dimana semua anggota populasi dijadikan sampel.

\section{Definisi operasional dan pengukuran variabel}

Variabel kualitas audit sebagai variabel laten endogen diukur dengan menggunakan indikator yang telah digunakan oleh Efendi (2010), yaitu keakuratan temuan, sikaf skeptisme, nilai rekomendasi, kejelasan laporan dan tindak lanjut hasil audit. Variabel laten eksogen dalam penelitian ini adalah kompetensi, independensi dan pengalaman kerja dan sistem pengendalian internal. Konstruk kompetensi diukur dengan indikator penguasaan terhadap standar akuntansi dan auditing, penguasaan terhadap objek audit 
dan proses peningkatan keahlian (Efendi, 2010). Konstruk independensi diukur dengan indikator yang telah digunakan oleh Pratiwi, et.al (2016) yaitu independensi di dalam program audit yang dijalankan, independensi di dalam verifikasi audit dan independensi di dalam pelaporan audit. Pengalaman kerja diukur dengan menggunakan indikator lama bekerja sebagai auditor dan banyaknya tugas pemeriksaan. Sistem pengendalian internal diukur dengan indikator yang mengacu pada PP Nomor 60 tahun 2008, yaitu lingkungan pengendalian, penilaian risiko, aktivitas pengendalian dan informasi dan komunikasi.

\section{Teknik analisis data}

Data dalam penelitian ini adalah data primer yang dikumpulkan melalui kuesioner. Kuesioner yang dikirimkan kepada responden memiliki tiga kemungkinan yaitu responden merespon, merespon tidak lengkap dan tidak merespon, sehingga metode ini memiliki kelemahan yaitu nonresponse bias (Sholihin dan Ratmono, 2013). Sehingga untuk mengatasi kelemahan tersebut dilakukan uji t sample independen untuk $30 \%$ sampel awal dan akhir, dengan menggunakan signifikansi 5\%.

Metode analisis data penelitian ini menggunakan Partial Last Square (PLS). Menurut hair, et.al (2010) PLS tepat digunakan untuk mereduksi data, yaitu dengan menentukan jumlah faktor minimum yang dibutuhkan untuk menghitung proporsi maksimum dari total varian yang direpresentasikan. Analisis data menggunakan SEM-PLS menurut Sholihah dan Ratmono (2013) dimulai dengan (1) Konseptualisasi model, (2) Mnentukan model analisis algoritm, (3) Menentukan metode resampling, (4) Menggambar diagram jalur, (5) Evaluasi model. Model penelitian ini dapat dirumuskan sebagai berikut:

$$
K A I=\beta_{1} \cdot K A+\beta_{2} \cdot I A+\beta_{3} \cdot P K A+\beta_{4} \cdot K A \cdot S P I+\beta_{5} \cdot I A \cdot S P I+\beta_{6} \cdot P K A \cdot S P I+\zeta
$$

Dimana:

$K A I=$ variabel laten endogen kualitas audit internal

$K A=$ variabel laten eksogen kompetensi auditor

$I A \quad=$ variabel laten eksogen independensi auditor

$P K A=$ variabel laten eksogen pengalaman kerja auditor

$S P I$ = variabel laten eksogen sistem pengendalian internal

$\mathrm{B} \quad=$ beta atau koefisien

$\zeta \quad=$ error model

\section{Evaluasi Model}

Evaluasi model berdasarkan SEM-PLS dilakukan dengan dua tahap yaitu evaluasi model pengukuran (outer model) dan evaluasi model struktural (inner model). Model pengukuran dilakukan untuk melakukan pengujian validitas dan reabilitas instrumen dalam model penelitian. Suatu instrumen dikatakan valid apabila memiliki nilai loading factor diatas 0,70 dan AVE diatas 0,05 untuk konstruk reflektif dan memiliki nilai p value dibawah 0,05 dan nilai VIF dibawah 3,3 untuk konstruk formatif (Ghazali dan Latan, 2015). Suatu instrumen dikatakan realibel apabila memiliki nilai Composite Reliability dan Cronbach's Alpha diatas 0,7 (Ghazali dan Latan, 2015).

Pengujian inner model dilakukan untuk menguji hubungan antar variabel laten. Hipotesis diterima apabila memiliki koefisien path $(\beta)>0$ dan $p$-value $<0,05$. Pengujian hipotesis moderasi dilakukan dengan melihat nilai total effect dan $\mathrm{p}$ value for total effect. Sistem pengendalian internal dikatakan memoderasi apabila memiliki nilai total effect $>0$ dan $\mathrm{p}$ value for total effect $<0,05$

\section{HASIL DAN PEMBAHASAN}

Penelitian ini menggunkan lima variabel antara lain kompetensi auditor, independensi auditor, pengalaman kerja auditor, sistem pengendalian internal dan kualitas audit internal. Kompetensi auditor, independensi auditor, pengalaman kerja 
auditor sebagai variabel independen, sistem pengendalian internal sebagai variabel moderasi dan kualitas audit internal sebagai variabel dependen. Pengujian statistik deskriptif digunakan untuk memperoleh gambaran atau karakteristik mengenai data yang meliputi nilai terendah (minimum).

Tabel 1. Statistik Deskriptif

\begin{tabular}{cccccc}
\hline & N & Minimum & Maksimum & Rata-rata & $\begin{array}{c}\text { Std. } \\
\text { Deviation }\end{array}$ \\
\hline Kompetensi & 47 & 3,7 & 5 & 4,117 & 0,3053 \\
Independensi & 47 & 1,2 & 5 & 3,987 & 0,6645 \\
PengalamanKerja & 47 & 3,8 & 5 & 4,24 & 0,3814 \\
SPI & 47 & 3,1 & 4,8 & 3,945 & 0,3006 \\
KualitasAudit & 47 & 3,6 & 5 & 4,134 & 0,3577 \\
\hline
\end{tabular}

Sumber: Data diolah

Tabel diatas menunjukkan bahwa Kompetensi memiliki nilai standar deviasi yaitu 0,30553, nilai tersebut lebih rendah dari nilai rata-rata, sehingga menunjukkan pada saat pengamatan terdapat variasi yang rendah antara nilai minimum 3,7 dan nilai maksimim 5.0. Kompetensi memiliki nilai standar deviasi yaitu 0,30553, nilai tersebut lebih rendah dari nilai rata-rata, sehingga menunjukkan pada saat pengamatan terdapat variasi yang rendah antara nilai minimum 3,7 dan nilai maksimim 5.0. Pengalaman kerja memiliki nilai standar deviasi yaitu 0,3814 nilai tersebut lebih rendah dari nilai rata-rata, sehingga menunjukkan pada saat pengamatan terdapat variasi yang rendah antara nilai minimum 3,8 dan nilai maksimim 5,0. Sistem pengendalian internal memiliki nilai standar deviasi yaitu 0,3006 nilai tersebut lebih rendah dari nilai rata-rata, sehingga menunjukkan pada saat pengamatan terdapat variasi yang rendah antara nilai minimum 3,1 dan nilai maksimim 4,8. Kualitas audit memiliki nilai standar deviasi yaitu 0,3577 nilai tersebut lebih rendah dari nilai rata-rata, sehingga menunjukkan pada saat pengamatan terdapat variasi yang rendah antara nilai minimum 3,6 dan nilai maksimim 5,10.

Kuesioner disebarkan kepada responden yaitu auditor yang bekerja di Inspektorat Provinsi Maluku, Kota Ambon dan kabupaten SBB. Kuesioner yang disebarkan berumlah 61, namun kuesioner yang kembali hanya 47 (70\%) dan kuesioner yang tidak kembali berjumlah 14 (30\%). Kuesioner yang tidak kembali berjumlah 30\% dan sangat signifikan, sehingga dibutuhkan uji nonresponse biar, yang bertujuan untuk menguji apakah kuesioner yang kembali dapat mewakili kuesioner yang tidak kembali.

Tabel 2 Independent $t$ test

\begin{tabular}{|c|c|c|c|c|c|c|c|c|c|}
\hline \multirow{3}{*}{ Variabel } & \multicolumn{9}{|c|}{ Perbedaan Berpasangan } \\
\hline & \multirow{2}{*}{ Nilai $\mathbf{t}$} & \multirow{2}{*}{ df } & \multirow{2}{*}{ Sig } & \multirow{2}{*}{ Mean_aw } & \multirow{2}{*}{ Mean_ak } & \multirow{2}{*}{$\begin{array}{c}\text { Perbedaan } \\
\text { Rata-rata }\end{array}$} & \multirow{2}{*}{$\begin{array}{c}\text { Perbedaan } \\
\text { Kesalahan } \\
\text { Standar }\end{array}$} & \multicolumn{2}{|c|}{$\begin{array}{c}90 \% \text { Int } \\
\text { Kepercayaan }\end{array}$} \\
\hline & & & & & & & & Uper & Lower \\
\hline KA_aw - KA_ak & $-1,504$ & 26,00 & 0,15 & 4,064 & 4,242 & $-0,178$ & 0,118 & $-0,430$ & 0,073 \\
\hline IA_aw - IA_ak & $-0,796$ & 26,00 & 0,43 & 3,971 & 4,092 & $-0,121$ & 0,152 & $-0,435$ & 0,192 \\
\hline PKA_aw - PKA_ak & $-0,135$ & 26,00 & 0,89 & 4,285 & 4,307 & $-0,021$ & 0,159 & $-0,348$ & 0,305 \\
\hline KA_aw - KA_ak & $-3,283$ & 26,00 & 0,05 & 3,900 & 4,257 & $-0,357$ & 0,108 & $-0,580$ & 0,104 \\
\hline SPI_aw - SPI_ak & 1,212 & 26,00 & 0,23 & 3,964 & 3,814 & 0,150 & 0,123 & $-0,422$ & 0,404 \\
\hline
\end{tabular}

Sumber: Data olah 
Tabel 2 menyajikan hasil uji nonresponse bias menunjukkan nilai signifikansi untuk semua konstruk laten yaitu kompetensi auditor, independensi auditor, pengalaman kerja auditor, kualitas audit dan sistem pengendalian internal. Seluruh variabel memiliki nilai signifikansi lebih besar dari 0,05 yang berarti tidak signifikan, sehingga dapat disimpulkan bahwa tidak ada perbedaan antara responden yang merespons dan tidak merespons kuesioner. Dengan demikian diyakini bahwa responden yang tidak mengembalikan kuesioner memiliki jawaban yang sama dengan responden yang mengembalikan kuesioner.

\section{Measurement model analysis}

Evaluasi model pengukuran digunakan untuk melihat instrument dalam suatu penelitian valid dan reliabel. Penelitian ini meggunakan tipe variabel reflektif. Konstruk endogen yaitu kualitas audit menggunakan tipe variabel reflektif dan seluruh variabel eksogen serta variabel moderasi mengguakan tipe variabel reflektif.

Teble 3. Validity (convergent and discriminant) and reliability

\begin{tabular}{lcccccc}
\hline \multirow{2}{*}{ Instrumen } & \multicolumn{3}{c}{ Validity } & \multicolumn{2}{c}{ Reliability } \\
\cline { 2 - 7 } & P Value & AVE & $\begin{array}{c}\text { Loading } \\
\text { Factor }\end{array}$ & $\begin{array}{c}\text { Outer } \\
\text { Loading }\end{array}$ & $\begin{array}{c}\text { Composite } \\
\text { Reability }\end{array}$ & $\begin{array}{c}\text { Cronbach } \\
\text { Alpha }\end{array}$ \\
\hline Kompetensi & $<0,001$ & 0,63 & 0,844 & 0,815 & 0,894 & 0,851 \\
Independensi & $<0,001$ & 0,758 & 0,864 & 0,093 & 0,962 & 0,954 \\
Pengalaman kerja & $<0,001$ & 0,671 & 0,897 & 0,313 & 0,934 & 0,917 \\
SPI & $<0,001$ & 0,739 & 0,857 & 0,313 & 0,944 & 0,927 \\
Kualitas Audit & $<0,001$ & 0,664 & 0,849 & 0,247 & 0,908 & 0,873 \\
\hline
\end{tabular}

Sumber: data diolah

Berdasarkan tabel 3, uji validitas konvergen dan diskriminan untuk variabel penelitian. Validitas konvergen untuk semua konstruk memiliki nilai $p$ value $<0,001$ dan memiliki nilai AVE >0,5 dan uji validitas konvergen dapat dilihat dari nilai outer loading faktor, p value dan akar AVE. Berdasarkan tabel 3, semua konstruk reflektif memiliki nilai outer loading diatas 0,7 , nilai $\mathrm{p}$ value $<0,001$ dan nilai akar AVE diatas 0,5 . Uji validitas diskriminan untuk konstruk reflektif dilihat dari nilai outer loading factor dan akar kuadrat AVE. Berdasarkan tabel 3 nilai semua outer loading lebih kecil dari nilai loading factornya dan nilai akan kuadrad AVE lebih besar dari korelasi antar variabel. Sehingga dapat disimpulkan bahwa konstruk penelitian telah memenuhi uji validitas konvergen dan diskriminan.

Uji reliabilitas untuk konstruk penelitian diukur dengan menggunakan composite reliability dan cronbach alpha. Berdasarkan tabel 3 nilai composite reliabiliti dan cronbach alpha memiliki nilai diatas 0,7 , sehingga semua konstruk dalam penelitian ini telah memenuhi uji reliabilitas.

\section{Structural model analysis}

Evalusi model struktural atau inner model digunakan untuk memprediksi hubungan antar variebel laten. Hasil pengujian model struktural (inner model) dapat dilihat pada nilai R-Square (R2) untuk konstruk eksogen dan nilai koefisien path untuk konstruk endogen. Hasil pengujian model struktural dengan menggunakan PLS ditampilkan pada tabel 4. 
Tabel 4. Pengujian Hipotesis

\begin{tabular}{lcccc}
\hline \multicolumn{1}{r}{ Pengujian } & Koefisien path & P Value & R-Square & Keterangan \\
\hline $\mathrm{KA} \rightarrow \mathrm{KAI}$ & 0,15 & 0,14 & & Ditolak \\
$\mathrm{IA} \rightarrow \mathrm{KAI}$ & 0,59 & $<0,01$ & & Diterima \\
$\mathrm{PKA} \rightarrow \mathrm{KAI}$ & 0,37 & $<0,01$ & & Diterima \\
$\mathrm{KA}{ }^{*} \mathrm{SPI} \rightarrow \mathrm{KAI}$ & 0,075 & $<0,01$ & 0,7 & Diterima \\
$\mathrm{IA}$ SPI $\rightarrow$ KAI & 1,01 & $<0,01$ & & Diterima \\
$\mathrm{PKA}^{*}$ SPI $\rightarrow$ KAI & 0,39 & $<0,01$ & & Diterima \\
\hline
\end{tabular}

Tabel 4, menunjukkan bahwa pada pengujian efek langsung, kompetensi auditor tidak berpengaruh terhadap kualitas audit internal, karena memiliki nilai $\mathrm{p}$ value diatas $0,05(0,14)$. Hasil penelitian ini menolak teori atribusi yang dikemukakan oleh Fritz Heider, yang mengungkapkan bahwa prilaku auditor dalam memberikan opini audit sangat dipengaruhi oleh kompetensi, sehingga kompetensi yang baik dari auditor akan menghasilkan opini audit yang obyektif terhadap auditee. Namun pada temuan ini membuktikan bahwa keputusan auditor tidak dipengaruhi oleh kompetensi yang dimilikinya. Hasil penelitian ini sejalan dengan studi yang dilakukan oleh Harsanti dan Whetyningtyas (2014), Ilham et. al. (2018) yang menemukan kompetensi auditor tidak berpengaruh terhadap kualitas audit. Hal ini dikarenakan auditor belum mampu menemukan adanya pelanggaran dalam laporan keuangan klien sehingga tidak berpengaruh terhadap kualitas audit. Hasil penelitian ini bertolak belakang dengan teori yang mengungkapkan bahwa salah satu faktor yang mempengaruhi kualitas audit adalah kompetensi, karena kompetensi yang tinggi akan menjadikan auditor memiliki lebih banyak pengetahuan dalam bidang yang digelutinya, sehingga auditor tersebut akan dapat mengerti masalah-masalah yang ditemui secara lebih mendalam.

Independensi berpengaruh terhadap kualitas audit internal. Penelitian ini mendukung teori atribusi yang mengungkapkan bahwa motif dan prilaku auditor dalam melaksanakan fungsi audit dipengaruhi faktor internal, yaitu faktor yang melekat pada dirinya. Salah satu faktor tersebut adalah independensi, sehingga semakin independen seorang auditor dalam melaksanakan perikatan audit, maka akan menghasilkan audit yang berkualitas. Hasil penelitian ini sejalan dengan studi yang dilakukan oleh Harsanti dan Wetiningtyas (2014), Sinambela (2019), mengungkapkan bahwa semakin auditor mampu menjaga independensinya dalam menjalankan penugasan profesionalnya maka kualitas audit yang dihasilkan akan meningkat. Haryanto dan Susilowati (2018) mengungkapkan bahwa apabila seorang auditor internal tidak dipengaruhi oleh pihak lain maupun kepentingan pribadi maka auditor akan menyatakan pendapatnya berdasarkan pertimbangan fakta-fakta yang ada, hal itu berarti semakin tinggi independensi yang dimiliki oleh auditor internal semakin baik pula kualitas audit yang dihasilkannya. Studi Ramadhani (2012) dan Syahputra, et.al (2015) mengungkapkan bahwa independensi tinggi yang ditunjukkan oleh auditor akan menghasilkan audit yang berkualitas.

Pengalaman kerja ber-pengaruh terhadap kualitas audit internal. Pengalaman auditor merupakan pengalaman dalam melakukan audit atas laporan keuangan dan pembelajaran atas dari kejadian-kejadian masa lalu dan pengalaman audit dapat dilihat dari lamanya waktu dan banyaknya penugasan audit yang pernah diselesaikan. Semakin banyak tugas audit yang diselesaikan oleh auditor maka akan menghasilkan audit yang berkualitas, hal ini dikarenakan auditor akan mudah menemukan kesalahan dan akan lebih teliti dalam melakukan pemeriksaan. Hasil penelitian ini sejalan dengan penelitian yang dilakukan oleh Syahputra, et.al (2015) yang melakukan studi pada Inspektorat Kabupaten Bireuen, yang mengungkapkan bahwa pengalaman auditor yang tinggi sangat mempengaruhi hasil audit yang merupakan kualitas audit dan kinerja auditor tersebut. Dewi (2016) melakukan studi pada Inspektorat Provinsi Daerah Istimewa Yogyakarta, 
mengungkapkan bahwa semakin banyak Pengalaman kerja seorang auditor maka Kualitas Audit yang dihasilkan akan semakin baik. Imansari dan Halim (2017) mengungkapkan bahwa semakin banyak pengalaman audit maka semakin tinggi tingkat kesuksesan dalam melaksanakan audit, sehingga audit yang dihasilkan akan berkualitas.

Sistem pengendalian internal memperkuat hubungan kompetesi, independensi dan pengalaman kerja terhadap kualitas audit internal, hal ini dapat dilihat dari nilai $\mathrm{p}$ value dan nilai path coefisien. Sistem pengendalian internal adalah alat untuk memberikan keyakinan memadai bahwa tujuan pengendalian manajemen akan tercapai. Semakin baik Inspektorat menerapkan pengendalian internalnya maka akan membantu memastikan untuk mendapatkan kualitas audit yang baik. Hasil penelitian ini mendukung teori stewardship yang mengungkapkan bahwa auditor akan bekerja untuk kepentingan bersama. Sistem pengendalian internal mendorong auditor yang memiliki kompetensi untuk bekerja dengan maksimal, sehingga tercapai tujuan bersama. Hasil penelitian ini sejalan dengan penelitian yang dilakukan oleh Aristanti (2011), yang mengungkapkan bahwa sistem pengendalian internal yang lemah akan menghasilkan laporan audit yang lemah, oleh karena itu dalam upaya meningkatkan kualitas audit internal maka harus didukung dengan sistem pengendalian internal yang kuat.

\section{KESIMPULAN DAN SARAN}

Berdasarkan analisis dan pembahasan, faktor-faktor yang digunakan untuk meningkatkan kualitas audit internal adalah kompetensi auditor, independensi, pengalaman kerja dan yang disertai dengan sistem pengendalian internal yang baik. Pada prinsipnya kompetensi auditor merupakan salah faktor yang sangat menentukan kualitas audit, hal ini dikarenakan auditor yang kompeten akan mudah mendeteksi masalahmasalah auditee dan auditor yang kompeten pasti memiliki banyak pengetahuan terkait bidang yang digelutinya. Temuan penelitian ini mengungkapkan bahwa kompetensi auditor bukan menjadi faktor yang dapat meningkatkan kualitas audit, hal ini karena berdasarkan identifikasi peneliti auditor internal pada obyek penelitian masih memiliki kompetensi yang belum memenuhi standar, sehingga dapat dilihat dari opini audit yang diterima obyek penelitian selama beberapa tahun terakhir.

Independensi menjadi salah satu faktor yang dapat digunakan untuk meningkatkan kualitas audit internal, hal ini karena independensi merupakan sikap mental yang harus dimiliki seorang auditor dalam melaksanakan audit, sehingga auditor harus berprilaku independence in fact dan independence in appearance. Faktor lain yang mempengaruhi kualitas audit adalah pengalaman kerja auditor, karena auditor yang berpengalaman akan mudah mendeteksi kesalahan dan lebih teliti dalam melakukan proses audit. Pengalaman audit dapat dilihat dari lama waktu dalam menjalani profesi dan banyaknya perikatan audit yang telah diselesaikan, sehingga semakin banyak pengalaman auditor maka akan menghasilkan audit yang berkualitas. Sistem pengendalian internal yang baik pada suatu inspektorat akan meningkatkan kualitas audit internal yang didukung dengan kompetensi, independensi dan pengalaman kerja audito.

\section{REFERENSI}

Abiola, I., \& Oyewole, A. T. (2013). Internal control system on fraud detection: Nigeria experience. Journal of Accounting and Finance, 13(5), pp: 137.

Aristanti Widyaningsih, et al. (2011). The Relationship between the Effectiveness of the Regional Financial Accounting System and Internal Control with the Quality of Financial Accountability: The Quality of Financial Statement Information as an Intervening Variable, in SNA XIV. Aceh.

Dewi, C.A. (2016). the effect of work experience, competence, and independence on audit quality with auditors' ethic as the moderation variable. Jurnal Profita Edisi 8 Tahun 2016, Vol 3 Noomor 2. 
Efendy, M. (2010). Effect of Competence, Independence, and Motivation on Audit Quality of Inspectorate Officers in Regional Financial Oversight (Empirical Study on Gorontalo City Government). Diponegoro University.

Haryanto, Sahmuddin, dan Arifuddin. (2007). "Public sector accounting". First Edition: Diponegoro University. Semarang

Harsanti, P dan Whetyningtyas, A. (2014). Influence of Auditor Competence, Independence, and Professionalism on Audit Quality (Empirical Study in Public Accounting Firm in Semarang). Journal of Financial Accounting. Volume 7, Nomor 1, Juni 2014

Gamar, N. Djamhuri A. (2015). Internal Auditors as Fraud "Doctors" in Local Government. Journal of Multiparadigm Accounting, Volume 6, Number 1, April 2015, p. 107-123.

Ghazali dan Latan. (2015). Structural Equation Modelling Alternative Method With Partial Last Square. Semarang. BP Diponegoro University.

Imansari, F.P dan Halim, A. (2017). Influence of auditor's competence, independence, experience and ethics on audit quality (empirical study on auditors of public accounting firms in Malang).Journal Riset Mahasiswa Akuntansi (JRMA). Volume: $\mathrm{xx}$, Nomor: $\mathrm{xx}$

Ilham, M., Suarthana, W. R., \& Suroto, S. E. (2018). Effect of Competence, Integrity and Motivation on Audit Quality (Empirical Study at Bogor City Inspectorate). Jom Vol 5 , No 5 (2018).

Indriantoro, N. Soepomo,B. (2016). M Business Research Methodology for Accounting and Management.Yogyakarta. BPFE

Parasayu, A., \& Rohman, A. (2014). Analysis of Factors Affecting the Quality of Internal Audit Results (Study of the Internal Government's Perception Apparatus of Surakarta City Government and Boyolali Regency). Diponegoro Journal Of Accounting, 3(2), 1-10.

Pratiwi, E., \& Nurkholis, A. (2016). The Mediation Role of Job Satisfaction on the Influence of Auditors' Independence and Professionalism towards the Internal Auditors' Performance. Imperial Journal of Interdisciplinary Research (IJIR), 2(12).

Ramadhanis, S. (2012). Effect of Competence, Independence and Motivation on Audit Quality in the Inspectorate. e-Jurnal Binar Akuntansi, 1(1).

Sinambela, Tongam. (2019). Effect of Competence, Independence, and Motivation on Audit Quality. Jurnal Bisnis dan Akuntansi Unserya Vol 4, No 1, Januari (2019).

Supriyono, R. (1988). Accounting Examination (Auditing) Factors affecting the Independence of Public Accountant Appearance. Yogyakarta: BPFE Publisher.

Syahputra, A., Arfan, M., \& Basri, H. (2015). Influence of Competence, Independence, Experience, and Integrity on the Quality of Government Internal Audit Audit Quality(APIP). Jurnal Magister Akuntansi Pascasarjana Universitas Syiah Kuala, 4(3), 49-56.

Tuanaya, Taufik. (2016). The burkab regency is out of the opinion of the disclaimer of financial statements. www.terasmaluku.com, 17 November 2019. 